\title{
The contingent valuation for the preservation of three urban green parks
}

Urban green parks, considered as natural resources, should be strategic elements for conservation of natural resources, socialization, health and well-being, since it significantly influences the local economy. The research sought to quantify the Willingness to Pay (WTP) for environmental conservation and its influencing factors, indicated by the population using three urban parks in Campo Grande, MS, Brazil: Parque das Nações Indigenas (PNI); Parque Ayrton Senna (PAS); and Parque Matas do Segredo (PMS). It was a quantitative approach, interviewing 824 users from the three parks object of the research, highlighting those who know and frequent the parks. A structured questionnaire was used, divided into groups of variables to identify the perceptions of socioeconomic, maintenance and preservation of parks, satisfaction with the equipment offered, and with the environmental preservation and maintenance of the Parks. Descriptive statistics and Chi-square test were used to compare the independence between the proportions obtained for each Park, at the level of significance at $p<0.05$, bilateral. A binary logistic regression analysis of discrete variables was also performed to identify the factors that may influence the user of the Park to WTP of environmental conservation. As a result, it was identified that there is satisfaction in the Parks, in relation to the questions: place for social interaction, appearance, attractiveness, calm, cozy, beautiful and clean environment. In relation to WTP, it was identified that the people who attend the Parks are willing to pay for the protection and environmental conservation of these. This article has its academic importance in contributing to the knowledge of the importance of Urban Green Parks, as well as providing indications for the evolution of others socio-environmental research projects. Under the business scope, it provides data and conclusions for the direction of public policies enlist the population and entrepreneurs to strengthen the preservation and maintenance.

Keywords: Willingness to Pay; Environmental Valuation; Conservation; Urban Parks; Brazil.

\section{A avaliação contingente para a preservação de três parques verdes urbanos}

\begin{abstract}
Os parques verdes urbanos, considerados recursos naturais, devem ser elementos estratégicos para a conservação dos recursos naturais, socialização, saúde e bem-estar, uma vez que influencia significativamente a economia local. A pesquisa procurou quantificar a WTP (Disposição a Pagar) pela conservação ambiental e seus fatores de influência, indicados pela população em três parques urbanos de Campo Grande, MS: Parque das Nações Indígenas (PNI); Parque Ayrton Senna (PAS); e Parque Matas do Segredo (PMS). Foi uma abordagem quantitativa, entrevistando 824 usuários dos três parques objeto da pesquisa, destacando aqueles que conhecem e frequentam os parques. Utilizou-se um questionário estruturado, dividido em grupos de variáveis ?? ambiental dos Parques. A estatística descritiva e o teste do qui-quadrado foram utilizados para comparar a independência entre as proporções obtidas para cada parque, ao nível de significância em $p<0,05$, bilateral. Também foi realizada uma análise de regressão logística binária de variáveis ??discretas para identificar os fatores que podem influenciar o usuário do Parque à ETA de conservação ambiental. Como resultado, identificou-se que há satisfação nos Parques, em relação às questões: local de interação social, aparência, atratividade, ambiente calmo, aconchegante, bonito e limpo. Em relação à ETA, identificou-se que as pessoas que frequentam os Parques estão dispostas a pagar pela proteção e conservação ambiental destes. Este artigo tem sua importância acadêmica em contribuir para o conhecimento da importância dos Parques Verdes Urbanos, além de fornecer indicações para a evolução de outros projetos de pesquisa socioambiental. No âmbito do negócio, fornece dados e conclusões para a direção das políticas públicas, alistando a população e os empresários para fortalecer a preservação e manutenção.
\end{abstract}

Palavras-chave: Vontade de pagar; Avaliação Ambiental; Conservação; Parques urbanos; Brasil.

Topic: Desenvolvimento, Sustentabilidade e Meio Ambiente

Reviewed anonymously in the process of blind peer

José Francisco dos Reis Neto (iD

Universidade Anhanguera, Brasil

http://lattes.cnpq.br/9069806202978279

http://orcid.org/0000-0002-1152-1149

ifreisneto@terra.com.br

Michelle da Rosa Lopes

Universidade Anhanguera, Brasil

http://lattes.cnpq.br/4009157582818338

http://orcid.org/0000-0001-9851-2300

michelle.rosa@anhanguera.com

Celso Correia de Souza (iD)

Universidade Anhanguera, Brasil

http://lattes.cnpq.br/2881392515816773

http://orcid.org/0000-0002-2689-8264

csouza939@gmail.com

d

DOI: 10.6008/CBPC2179-6858.2020.003.0021
Received: 08/03/2020

Approved: 21/04/2020

Marlucy Ferreira Machado Xavier

Universidade Anhanguera, Brasil

http://lattes.cnpq.br/9695778278443083

http://orcid.org/0000-0001-5987-6195

marlucy.machado@anhanguera.com
Referencing this:

REIS NETO, J. F.; LOPES, M. R.; SOUZA, C. C.; XAVIER, M. F. M.. The contingent valuation for the preservation of three urban green parks. Revista Ibero Americana de Ciências Ambientais, v.11, n.3, p.251263, 2020. DOI: http://doi.org/10.6008/CBPC21796858.2020 .003 .0021 


\section{INTRODUCTION}

Preserving the environment or establish a sustainable exploration of natural resources can be associated to the social issues of the agents involved in the direct or indirect use. Based on this assumption the economy has sought to establish new theories to achieve what is usually called sustainable development (CAVALCANTI, 2004). In the 20th century, the environmental impact of society has multiplied in a way never witnessed before. The world population increased from 1.5 billion people in the year 1900 to 6.3 billion in 2003 (ANDRADE et al., 2011), and in that case there was considerable consumption of goods, causing an increase in the extraction of natural resources to meet the global consumerism, which brought impacts on the ecosystem, one of which is the reduction of biodiversity that can seriously affect life on earth in the future.

Environmental economics, states that the market has not been able to control the growing environmental problems by reason of the non-inclusion of environmental costs and of environmental externalities in the prices of goods and services (MAY, 2010). The market imperfection must be corrected by incorporating the values of externalities to the price of the product or environmental service. The positive or negative externalities, usually are not incorporated in the formations of prices, considered as external phenomena of the economy, that is usually isolated, the neoclassical economics and seeks to assign a replacement value to the lost social and environmental goods, considering that the economic development should be in the first place, regardless of resources included to the attributes and intrinsic losses, represented with the social and environmental impacts, in this way, after 1970 a new perception starts before the environmental scenario, including the impacts from pollution as a guide in decisions, through the environmental economics, deriving from the neoclassical economics, but considering the valuation of environmental resources available as guiding principal good in the pursuit of economic development, mitigating the externalities through fees or limiting certain emitters of pollutants, aiming at the event of existing the loss of the natural good, how much the population would lose of welfare (SACHS, 2008). Environmental economics is, in a simplified form, an adjustment performed by economists to include the environment in the neoclassical model. The focus of environmental economics, therefore, is to find the correct prices for allocation of resources so that the resources used have maximum benefit and minimum cost (CAVALCANTI, 2010) still, on the basis that natural resources are infinite and can be replaced by new technologies.

The Willingness to Pay (WTP), contingent valuation method (CVM) seeks to assess, monetarily, the impact on the level of the well-being of individuals as a result of quantitative or qualitative variation of environmental goods and services (MOTTA, 2006). Venkatachalam (2004) describes the contingent valuation as a method of research in which the respondents are asked how much they are willing to pay for the use or conservation of natural goods, listing their declared preferences and are considered contingents to alternative goods that are offered in a hypothetical market, the essential elements of the research are as follows: description of the natural good to be assessed, a description of the vehicle of payment and 
hypothetical market description, the description of the natural asset includes identifying all the valuable attributes of the good. The CVM is the most used as the approach to the identification and establishment of an instrument of public policies to mitigate the environmental impacts, presents empirical results before the current scenario and their possible lack in the future, deriving real values that may assist in the valuation of natural resources in search of well-being, these initiatives contribute to the perception of the population to examine the resources available through other visions, the perception of its importance and therefore valuing a monetary value to preserve this good (MAIA et al., 2004; LO et al., 2010).

Pindyck et al. (2002), corroborate results of empirical studies that people are willing to pay significantly more for pure air to the extent that the pollution level increases, and individuals with higher income are willing to pay more for fresh air. Studies show a similar analogy of a fictitious market in relation to the attribute of the natural resource, by means of environmental scenarios closer to the characteristics of reality, with values that reflect the population's willingness to pay to maintain and preserve the resources/environmental goods. Obviously, there are natural resources that cannot be replaced with their loss, so studies incorporate the reservations and maintenance of these resources, without access to the public, and the natural goods with more disposal a fee is charged to use or direct contribution, given that this willingness to pay or not by maintaining a natural asset will depend on how the population perceives, thus, public policies are fundamental to contribute with this environmental perception (ARRUDA et al., 2014). This availability to pay or not for a natural resource is considered a market failure, and this should be already developed by observing a scenario in the long term, its environment as a whole, valuing and respecting the natural resources and biodiversity (BARTELMUS, 2012).

The growth of population in large urban areas, impacts on the loss of green areas, areas that contribute and balance the urban environment, seeking to mitigate the impacts of pollution, and the reduction of the externalities of large urban centers, urban parks and reserves have environmental dichotomic role, instilling in the population perception to look more toward the environment and their need to observe the maintenance for future generations (CHEN et al., 2010; LATINOPOULOS et al., 2016). Urban parks considered the natural goods should be observed as well as the strategic elements for conservation of natural resources, socialization, health and well-being, since they have a significant influence on the local economy. Despite the importance of these areas, the provision of public goods is still very incipient compared with their demand. Many times, the population has realized the importance of environmental parks and green areas as a public good, of collective use, considering the responsibility for its preservation to public bodies (MOTTA, 2006), but recently, demonstrates the intention to share and contribute to these costs (ADAMS et al., 2003). The economic valuation, as the purpose of incorporating the costs and the benefits provided by urban parks, so that the "price" reflects the real scarcity of good, allows to measure the costs and benefits of environmental projects, aiming at a better allocation of available resources, either public or private (VANDERMEULEN et al., 2011).

Thus, the survey sought to explain, with empirical data, the research cited by the surveyed authors. The article had as a premise to list the results indicated by the WTP, observing its factors of influence, 
indicated by the population using three urban parks of Campo Grande, MS: Indigenous Nations Park (PNI); Ayrton Senna Park (PAS); and Matas do Segredo Park (PMS), and sought to identify, along the population, whether this is or is not motivated to make contributions to the quality of the environment and the preservation of existing resources in the parks under study. Also, explored the factors that influence the WTP. Organized into more three sections, as follows: in Material and Methods section, the areas under study are introduced, the approach to valuation and the process of primary data collection and analysis of data; Results and Discussion Section empirical results are presented from the WTP analysis; and, in the conclusions and Implications section the academic and managerial implications of the results are discussed.

\section{METHODOLOGY}

To meet the interpretation of the objectives of this chapter, a survey was adopted with a quantitative approach, based on representative samples of the population of Campo Grande, MS, Brazil, of those who know and attend the three Parks under study. This has led to consider that the results are taken as they constitute a portrait of the entire target population, specified as a descriptive research. Regarding the procedures, a survey of theoretical references and already published was carried out in order to know what had already been studied on the subject (GERHARDT et al., 2009). The data collection was performed under conditions of control and with people in the vicinity of the Parks who were willing to participate, and they were considered as an interest group, using structured procedures and a formal questionnaire for data collection. There was no identification of the respondent, ensuring confidentiality, and data were processed in numerical sets through statistical procedures.

The target population was comprised of individuals who attended the research objects: Indigenous Nations Park - PNI, occupies area of 119 hectares, and preserves an ecological reserve, located in the downtown of the city of Campo Grande: Ayrton Senna Park - PAS, with an area of 27 hectares, situated in the south side of Campo Grande, and Matas do Segredo Park - PMS, with an area of 170 hectares, located near the north side suburb of the city (see Figure 1).

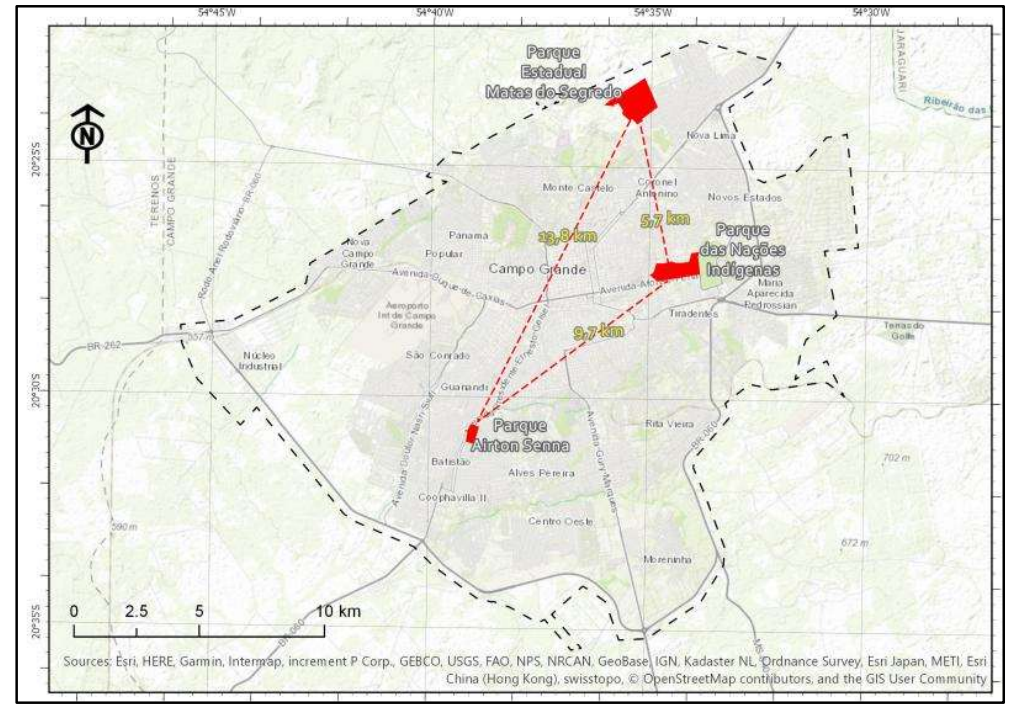

Figure 1. Location of the Three Urban Parks surveyed in the city of Campo Grande and respective distance between them. Source: PLANURB Geoprocessing Division (Municipal Institute of Urban Planning), Campo Grande, MS. 
In the applied questionnaire there was a group of variables of socioeconomic identification of the researched person: age, gender, level of education, work and pay. Another group of variables of perception of environmental preservation of the Park was included: interest in ecology, importance of preservation, level of concern and action of the Government, quantity of requests to the object of study, share of the economic value (WTP) to preserve the Park (ADAMS et al., 2003).

A pre-test was performed with a small number of users of PNI to check whether the questionnaire was logical and without ambiguities. Then, the questionnaires were applied in the surroundings of the three parks, during 04/16/2018 to 06/08/2018. The interviews, face-to-face, were administered by trained researchers, accredited and hired at Manoel de Barros Foundation - FMB, to the people who were willing to do them, constituting a non-probabilistic convenience sample.

A total of 824 complete questionnaires were used in the statistical techniques. Whereas the estimated population in Campo Grande, in the order of 874,210 people in 2017 (IBGE, 2010). The size of the sample of the target population in each Park was estimated for a significance level of $95 \%$, sample error of $5 \%$ and the probability of positive response $p=0.5$. This sample was considered statistically acceptable. They also meet the assumptions indicated by Hair Junior et al. (2009), as a rule of thumb for the techniques of data multivariate analysis, considering that five to six observations per item, or observed variable, are enough to explain the relevant statistical events.

The variables and measures of study, started in the perception of environmental preservation of the Parks through the indications, regarding: interest in ecology; importance of preservation; existing attributes in the parks; the perceptions of respondents regarding the factors, such as: cleaning, noises, security, green, animals, maintenance, lighting; level of concern and action of the Government; quantity of requests to the object of study; share of economic value (WTP) to preserve the Parks (ADAMS et al., 2003; MITCHELL et al., 2013)

For the submission of the summary and the socioeconomic variables under study (place of residence, attitude and general satisfaction) contingency tables were used with the observed frequencies, descriptive statistics and Chi-square test was used for the comparison of independences among the proportions obtained for each Park, at a significance level of $p<0.05$, bilateral.

The unidimensionality of the latent variables composed by a set of independent or observed variables, was measured by Cronbach's alpha coefficient. This is conceptualized as the measure of reliability, understood as the evaluation of consistency among multiple measures of a variable, which ranges from 0 to 1 , allowing the determination of the internal consistency of a group of variables in a single latent variable, to measure the same characteristics. The lower limit of the Cronbach alpha coefficient, for exploratory research, is 0.60 , and generally accepted for other studies the value of 0.70 .

A binary logistic regression analysis of discrete variables was performed to identify factors that may influence the user of the Park to the WTP of environmental conservation. If a respondent is willing to pay, or not, he was framed in a model of binary choice. Considering a dichotomic variable WTP equals to 1 if the respondent is willing to pay and 0 otherwise, it is possible to obtain what are the factors that affect WTP. The 
model of probability of WTP, P (WTP=1), was represented by the equation 1:

$$
\begin{gathered}
\ln \left[\frac{P(W T P=1)}{1-P(W T P=1)}\right]==\beta_{0}+\beta_{1}(\text { Sex })+\beta_{2}(\text { Age })+\beta_{3}(\text { Education })+\beta_{4}(\text { Income })+ \\
\beta_{5}(\text { Local })+\beta_{6}(\text { Attitude })+\beta_{7}(\text { Satisfaction })
\end{gathered}
$$

In the model it was considered that $H_{0}: \beta_{n}=0$, where $n=1,2,3,7$, at a significance level of $p<0.05$, determines the rejection or acceptance of the null hypothesis. If the null hypothesis is rejected, there is an indication that the variable in the model of binary logistic regression has significance in influence on people for the WTP for environmental conservation. To meet the best interpretation of binary logistic regression, the new scales of independent variables observed in new categories were adjusted, Sex $(1=$ female, $0=$ Male), location ( $1=$ Close, $0=$ other distances), Attitude $(1=$ Negative - the sum of the scales Completely against and In parts against, $2=$ Neutral, $3=$ Positive - the sum of the scales In favor, In parts and Totally in favor). The variable general satisfaction was also adjusted in relation to its quartiles, with the new scale $1=$ Low $(>4.3 ; 1$ st quartile) $2=$ Neutral ( 4.3 to $6.1 ; 2$ nd quartile) $3=$ High ( $>6.1 ; 3$ rd quartile).

The multicollinearity of the samples for each of the three parks was estimated by the statistics of Tolerance. The existence of intercorrelations among the variables was considered when observing tolerance values smaller than 0.1 among independent variables. In the model, all the independent variables, or predictors, showed tolerance values greater than 0.830 (variable Family Income) and Pearson's linear correlation of less than $0.347(p<0.001)$. The logistic regression does not presuppose the homogeneity of variance and normality of residues (FÁVERO et al., 2009).

For the evaluation of the quality of the model adjustment the test of Hosmer and Lemeshow was used, which compares the observed and expected frequencies of events and non-events to evaluate whether the model fits well the data. If the $p$-value of the test of quality of the adjustment is less than the significance level of $p<0.05$, the predicted probabilities deviate from the probabilities observed in a way that the binomial distribution does not predict it (HAIR JUNIOR et al., 2009). The $\mathrm{R}^{2}$ Nagelkerke was used for the assessment of the amount of explained variance in the dependent variable WTP by the model, of a minimum of 0 to a maximum of approximately 1 (PALLANT, 2016).

The percentage of correct prediction of the model evaluates the amount of cases that the model classifies as having the same characteristic presented in the observed group. The higher the percentage of correct prediction, the better the fit of the model to prognosis of the dependent variable WTP (PALLANT, 2016)

The variables in the logistic regression equation gives us information on the contribution or importance of each variable as a predictor variable. Their statistical significance, assuming the null hypothesis that $B=0$, is evaluated by the Wald test for $p<0.05$. That is, the predictive variables (or independent) that have $p<0.05$ in their coefficient $B$, are the variables that contribute significantly to the prediction of the model (HAIR JUNIOR et al., 2009). Another useful information of the model is the indicator Exp (B), which provides the odds ratio for each independent variable, representing the probability of being in one of the categories of result when the value of a predictor increases by one unit (FÁVARO et al., 2009; PALLANT, 2016). The 
software SPSS v.24 (IBM, 2016) was used for the preliminary analysis of the data, determination of the descriptive statistics and of the analyzes of the logistic regressions of the data.

\section{Results and Discussion}

The socioeconomic characteristics of the sample are summarized in table 1 , for each one of the Evaluated Urban Parks.

Table 1: The socioeconomic characteristics of the interviewees in Campo Grande, MS, about the Urban Parks, in 2017.

\begin{tabular}{|c|c|c|c|c|c|c|c|c|c|}
\hline \multirow{3}{*}{\multicolumn{2}{|c|}{ Variable Item }} & \multicolumn{8}{|c|}{ Place of Research } \\
\hline & & \multicolumn{2}{|c|}{$\begin{array}{l}\text { Indigenous Nations } \\
\text { Park-PNI (A) }\end{array}$} & \multicolumn{2}{|c|}{$\begin{array}{l}\text { Ayrton Senna Park } \\
\text { - PAS (B) }\end{array}$} & \multicolumn{2}{|c|}{$\begin{array}{l}\text { Matas do Segredo } \\
\text { Park-PMS (C) }\end{array}$} & \multicolumn{2}{|c|}{ Total } \\
\hline & & $\mathrm{N}$ & $\%$ & $\mathrm{~N}$ & $\%$ & $\mathrm{~N}$ & $\%$ & $\mathrm{~N}$ & $\%$ \\
\hline \multirow[t]{2}{*}{ Sex } & Female & 185 & 45.3 & 81 & 38.6 & 95 & 46.1 & 361 & 43.8 \\
\hline & Male & 223 & 54.7 & 129 & 61.4 & 111 & 53.9 & 463 & 56.2 \\
\hline \multirow[t]{4}{*}{ Age range } & Up to 24 years old & $160^{C}$ & 39.2 & $69^{C}$ & 32.9 & 32 & 15.5 & 261 & 31.7 \\
\hline & 25 to 34 years old & 107 & 26.2 & 55 & 26.2 & 72 & 35.0 & 234 & 28.4 \\
\hline & 35 to 44 years old & 94 & 23.0 & 33 & 15.7 & $57^{B}$ & 27.7 & 184 & 22.3 \\
\hline & Over 45 years old & 47 & 11.5 & $53^{\mathrm{A}}$ & 25.2 & $45^{\mathrm{A}}$ & 21.8 & 145 & 17.6 \\
\hline \multirow[t]{3}{*}{ Education Level } & Elementary School & 43 & 10.5 & 35 & 16.7 & 23 & 11.2 & 101 & 12.3 \\
\hline & High School & 173 & 42.4 & 82 & 39.0 & $121^{\mathrm{A}, \mathrm{B}}$ & 58.7 & 376 & 45.6 \\
\hline & Upper Education & $192^{C}$ & 47.1 & $93^{C}$ & 44.3 & 62 & 30.1 & 347 & 42.1 \\
\hline \multirow[t]{4}{*}{ Family income } & up to $\mathrm{R} \$ 1000$ & $65^{B}$ & 16.1 & 18 & 8.6 & $48^{B}$ & 23.5 & 131 & 16.0 \\
\hline & $\begin{array}{l}\text { From } R \$ 1001 \text { to } \\
R \$ 3000\end{array}$ & 171 & 42.3 & 99 & 47.1 & 104 & 51.0 & 374 & 45.7 \\
\hline & $\begin{array}{l}\text { From } R \$ 3001 \text { to } \\
R \$ 5000\end{array}$ & 84 & 20.8 & $57^{c}$ & 27.1 & 29 & 14.2 & 170 & 20.8 \\
\hline & Over R\$ 5000 & $84^{C}$ & 20.8 & 36 & 17.1 & 23 & 11.3 & 143 & 17.5 \\
\hline \multirow{3}{*}{$\begin{array}{l}\text { Residence in relation } \\
\text { to the Park }\end{array}$} & Close & 188 & 46.8 & 96 & 45.7 & 103 & 50.0 & 387 & 47.3 \\
\hline & $\begin{array}{l}\text { Neither close nor } \\
\text { far }\end{array}$ & 106 & 26.4 & 70 & 33.3 & 67 & 32.5 & 243 & 29.7 \\
\hline & Far & $108^{C}$ & 26.9 & 44 & 21.0 & 36 & 17.5 & 188 & 23.0 \\
\hline \multirow[t]{2}{*}{ Attends the Park } & Yes & $336^{C}$ & 82.4 & $171^{c}$ & 81.4 & 55 & 26.7 & 562 & 68.2 \\
\hline & No & 72 & 17.6 & 39 & 18.6 & $151^{\mathrm{A}, \mathrm{B}}$ & 73.3 & 262 & 31.8 \\
\hline
\end{tabular}

The data in table 1 indicate that the three Parks attract users with a wide socioeconomic variety. In general, they are men, young, with high school formation, family income between $\mathrm{R} \$ 1,000$ to $\mathrm{R} \$ 3,000$ (US\$ 1.00 was equal to $\mathrm{R} \$ 3.15$, in August 2017), who live next to the Park and affirm that they attend it. Also, in Table 1, it is possible to distinguish the significant differences at $p<0.05$ bilaterally among the proportions of the sample of respondents for each Park, for the variables age, educational level, family income, residence in relation to the Park and frequency to the Park.

It was raised the level of satisfaction of the respondent user of Parks, in relation to a set of subjective and objective requirements. Table 2 presents the descriptive statistics, indicated by the mean and standard deviation, and the $t$ test for independent samples at a significance level of $p<0.05$. The general satisfaction was calculated based on the other 14 items, given the possibility of unidimensionality offered by the measure of reliability, Cronbach's alpha ( $\alpha>0.70)$.

The general satisfaction of the people that attend the PNI is greater than the other two Parks. However, it is commonly observed that the references to the parks have averages above 4, indicative of personal subjective personal satisfaction to the requirements: site for social conviviality, appearance, 
attractiveness, calm environment, cozy, nice and clean. As highlighted by Costa (2016) public policies for revitalization of abandoned areas, creating parks and squares instill the social and environmental issues in the population, being able to create the feeling of belonging and the environmental perception in individuals, where they create the responsibility to preserve these new areas. As for the services supplied to users of each Park such as vegetation, lighting, location, presence of wild animals and local sports practices have an acceptable level of satisfaction, although the lowest scores were for the Parks maintenance. Motta (1997), confirms that a person evaluates the structural and environmental attributes before purchasing a property, prove that the hedonic price is associated with several variables - the quality of air, water, preserved parks, no noise from traffic, etc. -, called vectors which, when related to the environmental value, alter the market value of the asset. PMS was the one that received the lowest ratings of satisfaction.

Table 2: Level of satisfaction in relation to the perceived characteristics in the Parks of Campo Grande, MS, in 2017.

\begin{tabular}{|c|c|c|c|c|c|c|}
\hline \multirow[t]{3}{*}{ Latent variable/Items } & \multicolumn{6}{|c|}{ Place of Research } \\
\hline & \multicolumn{2}{|c|}{$\begin{array}{l}\text { Indigenous Nations Park - } \\
\text { PNI (A) }\end{array}$} & \multicolumn{2}{|c|}{$\begin{array}{l}\text { Ayrton Senna Park - } \\
\text { PAS (B) }\end{array}$} & \multicolumn{2}{|c|}{$\begin{array}{l}\text { Matas do Segredo Park - } \\
\text { PMS (C) }\end{array}$} \\
\hline & $\mathrm{m}$ & sd & $\mathrm{m}$ & sd & $\mathrm{m}$ & sd \\
\hline General satisfaction $(\alpha=0.901)$ & $5.5^{\mathrm{B}, \mathrm{C}}$ & 1.15 & $4.9^{\mathrm{C}}$ & 1.08 & 4.6 & 1.17 \\
\hline Satisfaction in living close to the park & 5.0 & 2.21 & 4.9 & 1.88 & 4.7 & 1.72 \\
\hline Location for social coexistence. & $5.7^{\mathrm{B}, \mathrm{C}}$ & 1.65 & $5.3^{\mathrm{C}}$ & 1.50 & 4.7 & 1.72 \\
\hline Appearance & $5.8^{\mathrm{B}, \mathrm{C}}$ & 1.53 & $5.0^{C}$ & 1.53 & 4.4 & 1.72 \\
\hline Attractiveness & $5.7^{\mathrm{B}, \mathrm{C}}$ & 1.56 & $4.9^{\mathrm{C}}$ & 1.51 & 4.5 & 1.59 \\
\hline Calm & $5.8^{\mathrm{B}, \mathrm{C}}$ & 1.51 & 5.1 & 1.46 & 5.0 & 1.42 \\
\hline Cozy & $5.7^{\mathrm{B}, \mathrm{C}}$ & 1.54 & 4.9 & 1.55 & 4.7 & 1.61 \\
\hline Beautiful & $5.9^{\mathrm{B}, \mathrm{C}}$ & 1.54 & 5.0 & 1.52 & 4.6 & 1.85 \\
\hline Clean & $5.5^{\mathrm{B}, \mathrm{C}}$ & 1.76 & $4.8^{\mathrm{C}}$ & 1.50 & 4.2 & 2.04 \\
\hline Vegetation (trees, lawns, etc.). & $5.8^{\mathrm{B}, \mathrm{C}}$ & 1.64 & 5.0 & 1.49 & $5.4^{\mathrm{B}}$ & 1.24 \\
\hline Maintenance (restrooms, etc.) & 4.2 & 2.13 & $4.4^{\mathrm{C}}$ & 1.63 & 3.9 & 1.93 \\
\hline Lighting & 4.7 & 1.93 & 4.8 & 1.64 & 4.5 & 1.39 \\
\hline Location & $5.7^{\mathrm{B}, \mathrm{C}}$ & 1.70 & 5.1 & 1.49 & 4.7 & 1.57 \\
\hline $\begin{array}{l}\text { The presence of various animals (Birds, } \\
\text { Capybaras, etc.). }\end{array}$ & $6.1^{\mathrm{B}, \mathrm{C}}$ & 1.45 & 4.4 & 1.89 & $5.1^{B}$ & 1.37 \\
\hline Location for sports practice & $5.9^{\mathrm{B}, \mathrm{C}}$ & 1.55 & $5.6^{\mathrm{C}}$ & 1.44 & 4.5 & 1.73 \\
\hline
\end{tabular}

Legend: $\mathrm{m}$, mean; sd, standard deviation; $\alpha$, Cronbach's alpha, measure of reliability of items on the latent variable.

Note: 7-point Likert scale, ranging from 1= very dissatisfied to $7=$ very satisfied. In each column differences are indicated among the averages at a significance level of $p<0.05$, bilaterally, with the letters $A, B, C$.

Table 3: Attitudes and Priorities to Environmental Protection on the Urban Parks of the interviewed population, in Campo Grande, MS, in 2017.

\begin{tabular}{|c|c|c|c|c|c|c|c|}
\hline \multirow[t]{3}{*}{ Variables } & & \multicolumn{6}{|c|}{ Place of Research } \\
\hline & & \multicolumn{2}{|c|}{$\begin{array}{l}\text { Indigenous Nations } \\
\text { Park - PNI }\end{array}$} & \multicolumn{2}{|c|}{$\begin{array}{l}\text { Ayrton Senna } \\
\text { Park - PAS }\end{array}$} & \multicolumn{2}{|c|}{$\begin{array}{l}\text { Matas do Segredo } \\
\text { Park - PMS }\end{array}$} \\
\hline & & $\mathrm{N}$ & $\%$ & $\mathrm{~N}$ & $\%$ & $\mathrm{~N}$ & $\%$ \\
\hline \multirow{5}{*}{$\begin{array}{l}\text { Attitude to environmental } \\
\text { preservation }\end{array}$} & Totally against & 14 & 3.4 & 5 & 2.4 & 1 & 0.5 \\
\hline & A little against & 28 & 6.9 & 14 & 6.7 & 6 & 2.9 \\
\hline & Neither in favor nor against & 57 & 14.0 & 56 & 26.7 & 25 & 12.3 \\
\hline & Little in favor & 57 & 14.0 & 36 & 17.1 & 43 & 21.1 \\
\hline & Totally in favor & 252 & 61.8 & 99 & 47.1 & 129 & 63.2 \\
\hline \multirow[t]{4}{*}{ Environmental Priorities } & Environment & 104 & 25.5 & 36 & 17.1 & 37 & 18.0 \\
\hline & Economic growth & 35 & 8.6 & 38 & 18.1 & 37 & 18.0 \\
\hline & $\begin{array}{l}\text { Balance between the environment } \\
\text { and the economic growth }\end{array}$ & 204 & 50.0 & 102 & 48.6 & 117 & 56.8 \\
\hline & Does not Know & 65 & 15.9 & 34 & 16.2 & 15 & 7.3 \\
\hline
\end{tabular}

The perception of the population in preserving and protecting the environment is remarkable in the data above, it was observed in the three parks considerable feeling totally in favor, in the face of 
environmental issues. When the priorities were listed, more than $50 \%$, in general, considered that there are ways to reconcile the environment with economic growth. Serbidin et al. (2007) and Laurita-Pant et al. (2015), report that where there were difficulties in the population to observe the importance of environmental value, mainly related to economic growth, pointing out that many of the studies on environmental perception excluded forms of economic growth that may or may not spread in the same space.

The results presented in tables 2 and 3 shows that the attendants of the three parks are satisfied and sustain their environmental protection. Table 4 summarizes the WTP statistics. Of the people that attend the parks, $62.0 \%$ are willing to pay for the environmental protection of PNI, $45.2 \%$ for PAS and $35.4 \%$ for the PMS. Although a lot of people are not willing to pay anything, expressing the negative to the main reasons: already pay many taxes; environmental preservation is the responsibility of the government; they are already included in the IPTU (Building and Land Urban Tax); not everybody would pay; without conditions to contribute; I do not think it is right; they would not invest correctly the value; I do not think it is necessary; I have no interest; the government should pay; I do not find fair just a few pay and many destroy; increase the corruption and they would not invest correctly; if the government did not steal, it would be possible to protect better; among others. There were 324 answers with negative justifications to the willingness to pay for environmental preservation, being the most expressive - we already pay many taxes.

Table 4: Descriptive statistics of the WTP of the interviewed population, Campo Grande, MS, in 2017.

\begin{tabular}{|c|c|c|c|c|}
\hline \multirow{2}{*}{\multicolumn{2}{|c|}{ Variables }} & \multirow{2}{*}{\multicolumn{3}{|c|}{ Place of Research }} \\
\hline & & & & \\
\hline \multirow{7}{*}{$\begin{array}{l}\text { Willingness } \\
\text { to Pay } \\
\text { monthly } \\
\text { (R\$) }\end{array}$} & Yes & $\begin{array}{l}\text { Indigenous Nations Park - } \\
\text { PNI (A) } \\
212\end{array}$ & $\begin{array}{l}\text { Ayrton Senna Park - } \\
\text { PAS (B) } \\
95\end{array}$ & $\begin{array}{l}\text { Matas do Segredo Park - } \\
\text { PMS(C) } \\
53\end{array}$ \\
\hline & No & 196 & 115 & 133 \\
\hline & Mean & 21.02 & $36.36^{\mathrm{A}, \mathrm{C}}$ & 13.32 \\
\hline & Standard Deviation & 21.50 & 45.06 & 15.38 \\
\hline & LC low $95.0 \%$ to mean & 18.11 & 27.18 & 9.73 \\
\hline & LC high $95.0 \%$ to mean & 23.93 & 45.54 & 16.90 \\
\hline & Median & 15.00 & 20.00 & 10.00 \\
\hline
\end{tabular}

Notes: Results only for those people who are willing to pay. In each column differences are indicated among the averages at a significance level of $p<0.05$, bilaterally, with the letters $A, B, C$. US\$ 1.00 was equal to R\$ 3.15, in August 2017.

Another relevant fact, raised by the research with users of Parks, is related to the importance of the government in the preservation of the environment and the degree of their responsibility and of other entities. The users report, within a seven-point scale ( $1=$ no concern to $7=$ a lot of concern), that the Federal Government $(m=3.9$ and $s d=2.12)$, State Government $(m=4.1$ and $s d=2.00)$ are in a neutral position and the Municipal Government $(m=4.6$ and $s d=2.09)$ a little concerned with the environment preservation. As to the degree of responsibility, they score the Federal Government $(m=4.7$ and $s d=2.24)$, State Government ( $m=5.0$ and $s d=2.09)$ and Municipal Government $(m=5.2$ and $s d=2.06)$ with very similar levels of concern. They also 
point out that the population ( $\mathrm{m}=5.3$ and $\mathrm{sd}=1.97)$ and non-governmental organizations $(\mathrm{m}=5.3$ and $\mathrm{sd}=$ 1.92) are more worried with responsibility for the preservation of the environment than government organizations. The descriptive statistics of the mean, standard deviation, confidence limits above and below the level of 95\% and the median of WTP for each one of the Parks evaluated are shown in table 4.

It should be noted that the values of the medians are lower than the means, indicating that most people are willing to pay less than the average value for each Park, and that the WTP distribution is positive asymmetric limited by few taxpayers with high value. The WTP values vary from the lowest R\$ 9.73 for PMS to the highest R\$ 45.54 for PAS, within the limits of confidence at 95\%. Thus, the Willingness to Pay (WTP), contingent valuation method (CVM) seeks to assess, monetarily, the impact on the level of the well-being of individuals as a result of quantitative or qualitative variation of environmental goods and services (MOTTA, 2006).

Tietenberg et al. (2016), present important concepts which validate WTP for environmental goods in the following categories: value of use, value of option and non-use value, categories which are used to make up the TWTP. The main concern with the use of contingent valuation method is the bias in the responses, in case it is not clear and objective its empirical application, and thus, it presents five types of potential bias to contribute with the focus on research: (1) strategic bias, (2) information bias, (3) initial bias, (4) hypothetical bias, and (5) the observed discrepancy between the disposition to pay and disposition to accept (LABANDEIRA et al., 2008).

Table 5 indicates the reasons why people are willing to pay for the environmental preservation, as well as the prospects of the value of non-use and use. This Table 5 shows that the values of non-use are important. The value of use was the most indicated by $40.1 \%$ of users of PNI and $38.4 \%$ of the PMS, indicative of perception of recreation and tourism in the Parks. For PAS the highlight of the WTP for environmental preservation was for the value of option, concerning the preservation for use soon (ADAMS et al., 2003; MOTTA, 1997; MOTTA, 2006).

Still in Table 5, it is verified that the users of the Parks also indicate, even in a smaller proportion, that the value of existence is the reason for their contributions to the preservation of urban environmental reserves, under the aspects of non-use.

Table 5. Respondent's reason for WTP on the Urban Parks of Campo Grande, in 2017

\begin{tabular}{|c|c|c|c|c|c|c|c|}
\hline \multirow{3}{*}{ Variables } & & \multicolumn{6}{|c|}{ Place of Research } \\
\hline & & \multicolumn{2}{|c|}{$\begin{array}{l}\text { Indigenous Nations Park - } \\
\text { PNI }\end{array}$} & \multicolumn{2}{|c|}{ Ayrton Senna Park -PAS } & \multicolumn{2}{|c|}{$\begin{array}{l}\text { Matas do Segredo Park } \\
\text { PMS }\end{array}$} \\
\hline & & $\mathrm{N}$ & $\%$ & $\mathrm{~N}$ & $\%$ & $\mathrm{~N}$ & $\%$ \\
\hline \multirow[t]{4}{*}{ Reason for WTP } & Value of existence & 55 & 25.9 & 25 & 26.3 & 23 & 31.5 \\
\hline & Option Value & 66 & 31.1 & 38 & 40.0 & 19 & 26.0 \\
\hline & Value of use & 85 & 40.1 & 32 & 33.7 & 28 & 38.4 \\
\hline & Does not Know & 6 & 2.8 & 0 & 0.0 & 3 & 4.1 \\
\hline
\end{tabular}

Note: only those who were interviewed that are WTP.

According to Adams et al. (2003), the ratio of the value of existence with the natural asset is fundamental to understanding of all, indicating the need for a minimum stock considered as essential for the existence of all human beings and species in that biodiversity. Maia et al. (2004) contributes to the perception 
of the economic value of the natural resource, highlighting the difference between the value of direct use (equipared to use and direct consumption of the population, through extraction, visitation or activities that impact on the environmental resource); Value of indirect use (there are certain indirect benefits that people can take advantage when there is preservation of an environmental resource); and Option value (the generation of certain satisfactions that can be consumed directly or indirectly from the environmental good in the future).

The estimated values for the model of binary logistic regression are shown in Table 6. The model was used to identify and quantify the factors that influence the WTP for environmental preservation, in each one of the evaluated Parks. The model contains seven independent variables predictive and all of them were considered statistically significant $\left(\mathrm{x}^{2}\right)$, indicating that the model was able to distinguish the people who reported the events of Willingness to Pay, or not. The model presented an acceptable explained variance, according to the indications of $\mathrm{R}^{2}$ Nagelberke and by means of the percentage of correct classification probability of WTP, contributes or does not contribute. Table 6 shows that for all respondents, encompassing the three Parks, only the independent variables age range, education, place of residence and satisfaction with the Park, have statistically significant contribution to the model of WTP. When computed the interviewees of the three parks together, the most important predictor for WTP is the place of residence $(B=0.81, p<0.001)$, registering an odds ratio $(\operatorname{Exp}(B)=2.25)$. This indicates that people who live close to the parks have more than twice the WTP, than those who do not reside, controlled by other factors of the model.

Table 6: Results of the logistic regression model of the interviewees' answers about the Urban Parks of Campo Grande, MS, in 2017

\begin{tabular}{|c|c|c|c|c|c|c|c|c|}
\hline \multirow[t]{2}{*}{ Variables } & \multicolumn{2}{|c|}{ All $(n=824)$} & \multicolumn{2}{|c|}{$\mathrm{PNI}(\mathrm{n}=487)$} & \multicolumn{2}{|c|}{ PAS $(n=212)$} & \multicolumn{2}{|c|}{ PMS (n=125) } \\
\hline & $\mathrm{B}$ & $\operatorname{Exp}(B)$ & $\mathrm{B}$ & $\operatorname{Exp}(B)$ & $\mathrm{B}$ & $\operatorname{Exp}(B)$ & $\mathrm{B}$ & $\operatorname{Exp}(B)$ \\
\hline Sex & -0.06 & 0.94 & 0.18 & 1.20 & -0.07 & 0.93 & -0.92 & 0.40 \\
\hline Age range & $0.15^{* *}$ & 1.16 & $0.19^{* *}$ & 1.21 & 0.22 & 1.24 & 0.11 & 1.12 \\
\hline Schooling & $0.25^{* *}$ & 1.28 & 0.11 & 1.11 & 0.27 & 1.31 & 1.29 & 3.63 \\
\hline Family income & 0.15 & 1.16 & 0.02 & 1.02 & $0.49^{* *}$ & 1.64 & -0.25 & 0.78 \\
\hline Place of residence & $0.81^{* * *}$ & 2.25 & $0.86^{* * *}$ & 2.36 & 0.05 & 1.05 & $2.52^{* *}$ & 12.37 \\
\hline Attitude & 0.03 & 1.03 & 0.20 & 1.22 & -0.16 & 0.85 & $1.36^{* *}$ & 3.89 \\
\hline General satisfaction with the Park & $0.62^{* * *}$ & 1.85 & $0.36^{* *}$ & 1.41 & $0.61^{* *}$ & 1.85 & $1.27^{* *}$ & 3.55 \\
\hline Constant & $-2.44^{* * *}$ & 0.09 & $-1.95^{* * *}$ & 0.14 & $-2.83^{* *}$ & 0.06 & $-7.71^{* * *}$ & 0.00 \\
\hline Hosmer-Lemeshow test $\left(\chi^{2}\right)$ of the model & $14.84^{* *}$ & & $22.49^{* *}$ & & $13.99^{* *}$ & & $10.99^{* *}$ & \\
\hline $\mathrm{R}^{2}$ Nagelberke & 0.17 & & 0.13 & & 0.15 & & 0.62 & \\
\hline$\%$ of correct prediction & 68.4 & & 65.1 & & 66.0 & & 84.0 & \\
\hline
\end{tabular}

Legend: Level of significance: ${ }^{* *} p<0.05 ; * * * p<0.001$.

For PNI, the significant variables at $p<0.05$ to the WTP model were: range of age, place of residence and the satisfaction with the park. The population living near PNI has a probability of 2.36 times greater in contributing for the environmental preservation, than those who live far away. When analyzed the age range, the increase of age, i.e. the oldest have 1.21 times greater probability of WTP than the youngest ones. Still regarding PNI, the greater the general satisfaction with the park, 1.41 times more their WTP.

When analyzed the model for the WTP, only the predictive variables family income and general satisfaction are significant at $p<0.05$. The increase in family income increases 1.64 times the chance to WTP. The higher the general satisfaction with WTP, increases the probability of 1.85 in contributing to the 
environmental preservation. The variable related to the proximity of residence to the Park, was not evaluated as significant to the model, inferring that living near or far does not interfere in its WTP.

The population using PMS, the variables: place of residence, attitude and general satisfaction; are significant in the WTP prediction. The place of residence is the most relevant, indicating that those who live near PMS is 12.37 times morem willing to pay for the environmental conservation. The higher the preservationist attitude of the user of the park, 3.89 times greater chance of WTP, and the higher the general satisfaction, 3.55 times greater the probability of PMS.

\section{CONCLUSIONS}

The study herein provides evidence that a good portion of the population of the three urban parks of Campo Grande is prepared to pay for their environmental preservations. The results of the analysis illustrate that two factors, place of residence and general satisfaction with the park, are significant determinants on users' Willingness to Pay or Not to Pay. Although in the Parks also stand as relevant the age range, the family income and the attitude, the former have a greater contribution to WTP.

Therefore, with the aim of increasing awareness of the preservation of the environment in parks, the level of general satisfaction of the users must be increased, with actions of maintenance, cleaning and lighting, because they are the pre-requisites highlighted to satisfaction. Also, introducing programs of interpretation and dissemination of the offered equipment, biodiversity, of the natural landscape presented in the Parks. Although this has costs, a greater appreciation of the resources would likely result in higher contributions.

On the managerial aspects and public policies, it can be highlighted in the establishment of a program to collect funds necessary to meet the users' requirements in the environmental preservation of Parks. These funds could alleviate the possible financial difficulties in the maintenance of equipment, conservation and protection of biodiversity and ecosystems, as well as preserve the quality of the environment, preventing the degradation of natural resources.

The results would imply that the proper management of the fund would be vital. Many of the users who refused contributing claimed the mistrust in public management and that the levels of concern and degree of responsibilities of the governmental organs are smaller when compared with the population and the non-governmental organizations. Thus, if a program of collection of special funds for the preservation of the environment of Parks was created, this could be supervised by representatives of the public user independently to ensure the fund integrity.

This study addressed only the population of Campo Grande, MS, Brazil who knows and attends at least one of the Parks. The sample was transverse, voluntary, and non-probabilistic, which may cause some bias regarding the interviewee and the people's economic and financial context. It is possible that other interested parties can also be willing to contribute to the environment conservation. Therefore, the expansion of research in a longitudinal way is suggested, following the provisions to pay for the environment preservation. If the special fund is established, it is suggested to evaluate the variation of values and 
confidence related to its use in environmental conservation of these Urban Parks and other implemented in Campo Grande.

\section{REFERENCES}

ADAMS, C.; AZNAR, C. E.; MOTTA, R. S.; ORTIZ, R. A.; REID, J. Valoração econômica do Parque Estadual Morro do Diabo (SP). São Paulo: Páginas \& Letras, 2003.

ANDRADE, D. C.; ROMEIRO, A. R.. Degradação ambiental e teoria econômica: algumas reflexões sobre uma 'Economia dos Ecossistemas'. Economia, Brasília, v.12, n.1, p.3-26, 2011.

ARRUDA, C.; CARVALHO, F.. Inovações ambientais: políticas públicas, tecnologias e oportunidades de negócios. Rio de Janeiro: Elsevier, 2014.

BARTELMUS, P.. Sustainability economics: an introduction. New York: Routledge, 2012.

CAVALCANTI, C.. Uma tentativa de caracterização da economia ecológica. Revista Ambiente \& Sociedade, São Paulo, v.7, n.1, p.150-156, 2004. Dol: http://doi.org/10.1590/S1414-753X2004000100009

CAVALCANTI, C.. Concepções da economia ecológica: suas relações com a economia dominante e a economia ambiental. Estudos Avançados da USP, São Paulo, v.24, n.68, p.53-67, 2010. DOI: http://doi.org/10.1590/S0103$\underline{40142010000100007}$

CHEN, W.; JIM, C. Y.. Resident motivations and willingnessto-pay for urban biodiversity conservation in Guangzhou (China). Environmental Management, Berlin, v.45, p.10521064, 2010. DOI: http://doi.org/10.1007/s00267-010-9478$\underline{2}$

FÁVERO, L. P.; BELFIORE, P.; SILVA, F. L.; CHAN, B. L.. Análise de dados: modelagem multivariada para tomada de decisões. Rio de Janeiro: Elsevier, 2009.

GERHARDT, T. E; SILVEIRA, D. T.. Métodos de pesquisa. Porto Alegre: UFRGS, 2009.

HAIR JUNIOR, J. F.; BALCK, W. C.; BABIN, B. J.; ANDERSON, R. E.; TATHAM, R. L.. Análise multivariada de dados. 6 ed. Porto Alegre: Bookman, 2009.

IBGE. Instituto Brasileiro de Geografia e Estatística. Censo Demográfico de 2010. Panorama geral: Campo Grande, Mato Grosso do Sul. Campo Grande: IBGE, 2010.

IBM. International Business Machines. IBM SPSS Statistics for Windows. Armonk: IBM Corp, 2016.

LABANDEIRA, X.; LEÓN, C. J.; VÁSQEZ, M. X.. Economía ambiental. Madrid: Pearson Educación S. A., 2008.

LATINOPOULOS, D.; MALLIOS, Z; LATINOPOULOS, P.. Valuing the benefits of an urban park project: A contingent valuation study in Thessaloniki, Greece. Land Use Policy, Amsterdam, v.55, p.130-141, 2016. DOI:

http://doi.org/10.1016/j.landusepol.2016.03.020
LAURILA-PANT, M.; LEHIKOINEN, A.; UUSITALO, L.; VENESJÄRVI, R.. How to value biodiversity in environmental management?. Ecological Indicators, Amsterdam, v.55, p.111, 2015. DOI: http://doi.org/10.1016/j.ecolind.2015.02.034

LO, A. Y. H.; JIM, CY.. Willingness of residents to pay and motives for conservation of urban green spaces in the compact city of Hong Kong. Urban Forestry \& Urban Greening, Amsterdam, v.9, p.113-120, 2010. DOI: http://doi.org/10.1016/j.ufug.2010.01.001

MAIA, A. G.; ROMEIRO, A. R.; REYDON, B. P.. Valoração de recursos ambientais: metodologias e recomendações. Texto para Discussão, Campinas, n.116, p.1-39, 2004.

MAY, P. H.. Economia do meio ambiente: teoria e prática. Rio de Janeiro: Elsevier, 2010.

MITCHELL, R. C.; CARSON, R. T.. Using Surveys to Value Public Goods: The Contingent Valuation Method. New York: RFF Press, 2013. DOI: http://doi.org/10.4324/9781315060569

MOTTA, R. S.. Manual para valoração econômica de recursos ambientais. Rio de Janeiro: IPEA, 1999.

MOTTA, R. S.. Economia ambiental. Rio de Janeiro: FGV, 2006.

PALLANT, J.. SPSS Survival Manual: A step by step guide data analysis using IBM SPSS. 6 ed. London: McGraw Hill, 2016.

PINDYCK, R.; RUBINFELD, D. L.. Externalidades e bens públicos. São Paulo: Prentice Hall, 2002.

SACHS, I.. Desenvolvimento includente, sustentável sustentado. Rio de Janeiro: Garamond, 2008.

SERBIDIN, A.; CARR, D.; CASSELS, S.; JIANG, L.. Population and Environment. Annual review of Environment and Resources, Palo Alto, v.32, p.345-373, 2007. Dol: http://doi.org/10.1146/annurev.energy.32.041306.100243

TIETENBERG, T.; LEWIS, L.. Environmental \& Natural Resource Economics. 10 ed. New York: Routledge, 2016.

VANDERMEULEN, V.; VERSPECHT, A.; VERMEIRE, B.; VAN HUYLENBROECK, G.; GELLYNCK, X.. The use of economic valuation to create public support for green infrastructure investments in urban areas. Landscape and Urban Planning, Amsterdam, v.103, p.198-206, 2011. DOI: http://doi.org/10.1016/j.landurbplan.2011.07.010

VENKATACHALAM, L.. The contingent valuation method: a review. Environmental Impact Assessment Review, Amsterdam, v.24, n.1, p.89-124, 2004. DOI: http://doi.org/10.1016/S0195-9255(03)00138-0

A CBPC - Companhia Brasileira de Produção Científica (CNPJ: 11.221.422/0001-03) detém os direitos materiais desta publicação. Os direitos referem-se à publicação do trabalho em qualquer parte do mundo, incluindo os direitos às renovações, expansões e disseminações da contribuição, bem como outros direitos subsidiários. Todos os trabalhos publicados eletronicamente poderão posteriormente ser publicados em coletâneas impressas sob coordenação da Sustenere Publishing, da Companhia Brasileira de Produção Científica e seus parceiros autorizados. Os (as) autores (as) preservam os direitos autorais, mas não têm permissão para a publicação da contribuição em outro meio, impresso ou digital, em português ou em tradução. 